\title{
Chronic Inflammatory Demyelinating Polyneuropathy Accompanied by Hepatocellular Carcinoma
}

\author{
Fuminobu Sugai, Kazuo Abe, Tetsuo Fujimoto, Seiichi Nagano, Harutoshi Fujimura, Yoshiro Kayanoki*, \\ Osamu OshiKawa*, Eiji Yamasaki*, Sumio Kawata*, Yuji Matsuzawa* and Takehiko Yanagihara
}

We report a patient with chronic inflammatory demyelinating polyneuropathy (CIDP) accompanied by hepatocellular carcinoma (HCC). Due to the remarkable weakness in the lower limbs and loss of the position sense, he could not walk. On neurophysiological examination, he had impaired nerve conduction velocities. Biopsied nerve and muscle specimens demonstrated demyelination of nerve fibers and neurogenic degeneration of muscles. After steroid therapy he showed marked improvement in muscle strength and sensory function.

(Internal Medicine 36: 53-55, 1997)

Key words: chronic inflammatory demyelinating polyneuropathy (CIDP), paraneoplastic polyneuropathy, steroid-pulse therapy

\section{Introduction}

Paraneoplastic polyneuropathy may be caused by small cell carcinoma of the lung, ovarian or uterine neoplasm, or other systemic malignancies. However, axonal degeneration is the main neuropathological feature and demyelination is rare. We treated a patient with demyelinating sensorimotor polyneuropathy accompanied by hepatocellular carcinoma (HCC), who showed remarkable improvement after steroid therapy.

\section{Case Report}

A 54-year-old man noticed numbness in the lower limbs in November 1994. At that time, he was found to have HCC. A month later, he noticed numbness spreading to the upper limbs and muscle weakness in all limbs. By April 1995, he was unable to walk without assistance. He underwent a transcatheter arterial embolization procedure for $\mathrm{HCC}$ and received vitamin $\mathrm{B}_{12}$ without any improvement of the neurological condition. $\mathrm{He}$ was eventually transferred to our hospital in June 1995. Neurological examination revealed weakness predominantly in the distal muscles, and he could not walk without assistance. Grip power was $6 \mathrm{~kg}$ on the right and $5 \mathrm{~kg}$ on the left. His joint and vibratory senses were impaired especially in the lower limbs, and deep tendon reflexes were diminished in all limbs. Coordination and autonomic function were intact. On laboratory examination, serum aspartate aminotransferase (AST), alanine aminotransferase (ALT) and $\gamma$-glutamyltranspeptidase $(\gamma$-GTP) were slightly elevated to $46(0-30), 81(0-32)$ and 53 (9-51) IU/ $l$ and $\alpha$-fetoprotein was also increased. The antigens and antibodies for hepatitis virus type B were also positive. However, the antibody for hepatitis virus type $\mathrm{C}$ was negative. A glucose tolerance test was normal. The anti-galactocerebroside $\operatorname{IgM}$ was positive, but the antibodies for GM1 ganglioside and mycoplasma were not detected. Immunoelectrophoresis of serum did not show an M-protein peak. The protein in the cerebrospinal fluid (CSF) was elevated to $68 \mathrm{mg} / 100 \mathrm{ml}$ without any pleocytosis, and CSF IgG was also elevated to $12 \mathrm{mg} /$ $100 \mathrm{ml}$. On neurophysiological examination, the motor nerve conduction velocity was reduced to $32.6 \mathrm{~m} / \mathrm{s}$ with the right median nerve and to $28.2 \mathrm{~m} / \mathrm{s}$ with the right posterior tibial nerve. The amplitude was also reduced to $2.8 \mathrm{mV}$ with the right median nerve and to $0.6 \mathrm{mV}$ with the right posterior tibial nerve. Conduction block and temporal dispersion were absent. The sensory nerve conduction velocity was also reduced to $34.4 \mathrm{~m} /$ $\mathrm{s}$ with the right median nerve. The F-wave conduction velocity was reduced to $27 \mathrm{~m} / \mathrm{s}$ with the right median nerve and was not evoked with the right ulnar nerve. The somatosensory evoked potential showed a prolonged latency, but the central conduction time was normal. A biopsy of the peripheral branch of the superficial peroneal nerve was performed. On pathological examination of the epon-embedded semi-thin section, there were thinly-myelinated fibers without loss of myelinated fibers, considering the diameter of axons, and there was no evidence of vasculitis or inflammatory cell infiltration (Fig. 1). A teased fiber preparation revealed demyelination and remyelination in

From the Department of Neurology and *the Second Department of Internal Medicine, Osaka University Medical School, Osaka

Received for publication April 25, 1996; Accepted for publication October 25, 1996

Reprint requests should be addressed to Dr. Kazuo Abe, the Department of Neurology, Osaka University Medical School, 2-2 Yamadaoka, Suita, Osaka 565 
$50 \%$ of the fibers and axonal degeneration was found in only $4 \%$ of fibers (Fig. 2). HE-staining of the left peroneus brevis muscle revealed neurogenic degeneration with atrophy in small groups and small angular fibers.

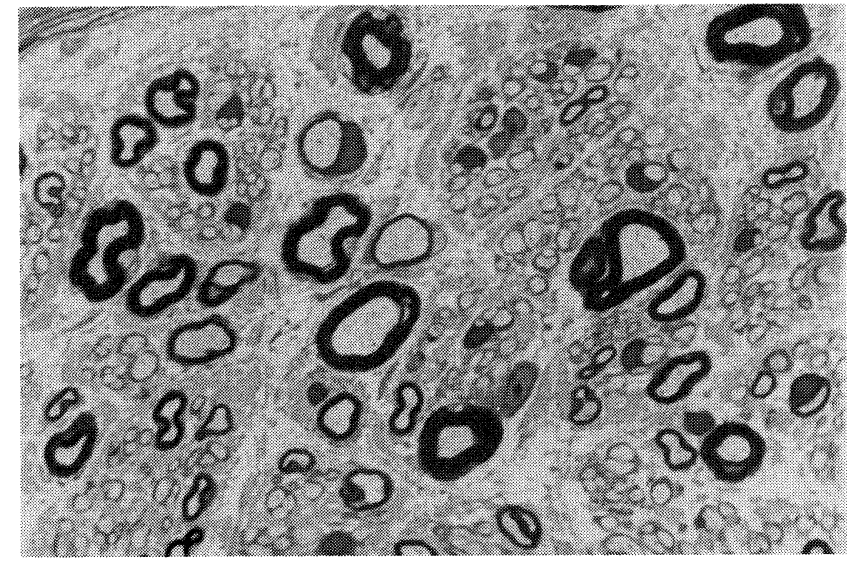

Figure 1. An epon-embedded semi-thin section of the left superficial peroneal nerve showing thinly-myelinated fibers or myelin overfolding, but without obvious loss of myelinated fibers (thionin stain, $\times 1,200)$.

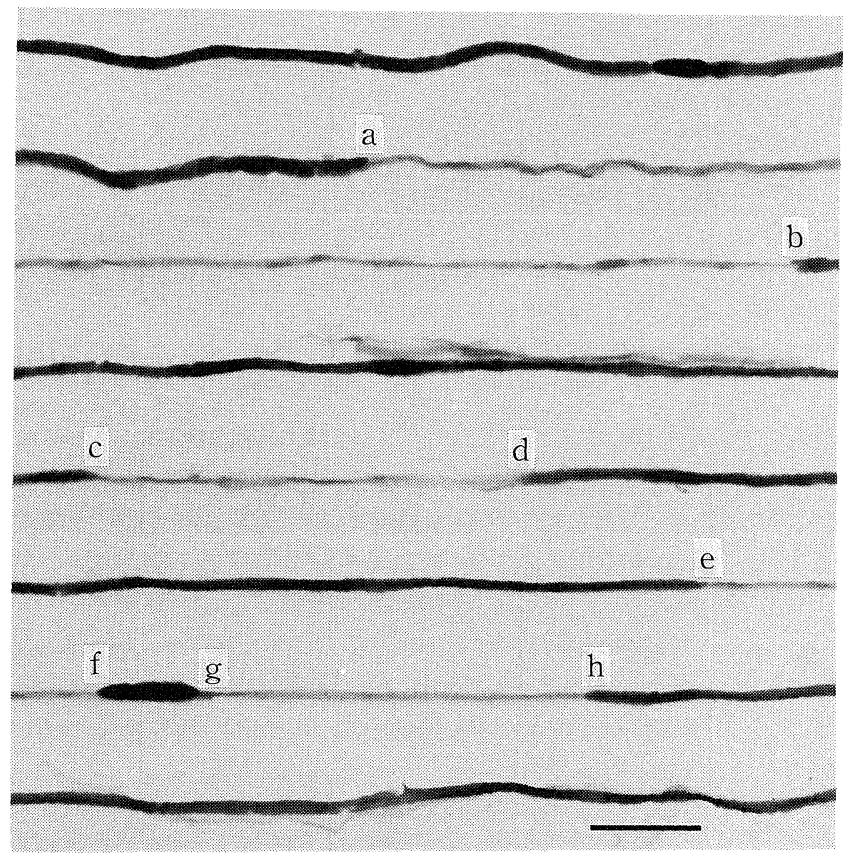

Figure 2. An isolated myelinated fiber (from top left to bottom right), demonstrating segmental de/remyelination between a and $b, c$ and $d, e$ and $f, g$ and $h(B a r=100 \mu m)$.

\begin{tabular}{|c|c|c|c|c|c|c|}
\hline $\begin{array}{c}\text { Methylprednisolone } \\
1 \mathrm{~g} / \text { day } \times 3 \text { days }\end{array}$ & & $\frac{12.7}{7 / 24-27}$ & & $\begin{array}{l}.9 \\
8 / 7-9\end{array}$ & & $\frac{17.9}{8 / 21-23}$ \\
\hline $\begin{array}{c}\text { Manual muscle test } \\
\text { Gastrocnemius } \\
\text { Tibialis anterior } \\
\text { (right/left) }\end{array}$ & $\begin{array}{l}1+/ 1+ \\
0 / 0\end{array}$ & & $\begin{array}{l}1 / 1 \\
3 / 3\end{array}$ & & & $\begin{array}{l}4 / 4 \\
4 / 4\end{array}$ \\
\hline \multicolumn{7}{|l|}{ Muscle strength } \\
\hline \multicolumn{7}{|l|}{ Gait disturbance } \\
\hline $\begin{array}{l}\text { F-wave }(\mathrm{m} / \mathrm{sec}) \\
\text { Right median } \\
\text { Right ulner }\end{array}$ & $\begin{array}{l}27.0 \\
\text { not evoke }\end{array}$ & & & & & $\begin{array}{l}45.7 \\
52.9\end{array}$ \\
\hline $\begin{array}{l}\text { *CMAP }(\mathrm{mV}) / \mathrm{MCV}(\mathrm{m} / \mathrm{s}) \\
\text { Right median } \\
\text { Right ulnar } \\
\text { Right posterior tibial }\end{array}$ & $\begin{array}{l}2.8 / 32.6 \\
3.3 / 38.0 \\
0.6 / 28.2\end{array}$ & & & & & $\begin{array}{l}7.2 / 39.0 \\
6.9 / 29.3 \\
0.32 / 29.1\end{array}$ \\
\hline $\begin{array}{l}\text { Cerebrospinal fluid } \\
\text { Cell }\left(/ \mathrm{mm}^{3}\right) \\
\text { Protein }(\mathrm{mg} / 100 \mathrm{ml}) \\
\text { IgG }(\mathrm{mg} / 100 \mathrm{ml})\end{array}$ & & $\begin{array}{r}1 \\
68 \\
12\end{array}$ & & & $\begin{array}{r}0 \\
46 \\
6\end{array}$ & \\
\hline $\begin{array}{l}\text { Liver enzymes }(\mathrm{IU} / l) \\
\text { AST } \\
\text { ALT } \\
\gamma \text {-GTP }\end{array}$ & & $\begin{array}{l}46 \\
81 \\
53\end{array}$ & & & $\begin{array}{l}49 \\
72 \\
32\end{array}$ & \\
\hline Date (1995) & $6 / 21$ & $7 / 4$ & & & $8 / 17$ & $8 / 31$ \\
\hline
\end{tabular}

Figure 3. Clinical course.

*CMAP: compound muscle action potential, MCV: motor nerve conduction velocity. 
Based on the criteria by the Ad Hoc subcommittee of the American Academy of Neurology (1), we diagnosed him to have chronic inflammatory demyelinating polyneuropathy (CIDP). He underwent steroid-pulse therapy with methylprednisolone $1,000 \mathrm{mg} /$ day for 3 days, which was repeated three times at about a 10-day interval. After the treatment, his motor ability and sensory function improved and he was able to walk without assistance. The F-wave conduction velocity also improved markedly to $45.7 \mathrm{~m} / \mathrm{s}$ with the right median nerve and $52.9 \mathrm{~m} / \mathrm{s}$ with the right ulnar nerve. The CSF protein and $\mathrm{IgG}$ contents were reduced to 46 and $6 \mathrm{mg} / 100 \mathrm{ml}$, respectively (Fig. $3)$. No oral corticosteroid therapy was administered subsequently for fear of an adverse effect to HCC. While he was in the hospital, transcatheter arterial embolization was carried out three times but his HCC remained unchanged. All through the course, serum liver enzymes (AST, ALT and $\gamma$-GTP) changed little.

\section{Discussion}

Paraneoplastic polyneuropathy is usually associated with small cell carcinoma of the lung and neoplasm of the ovary or uterus. Sensorimotor dominant paraneoplastic polyneuropathy is characterized by degeneration of the dorsal column of the spinal cord and axonal degeneration (2-4). Successful treatment has not been found for paraneoplastic polyneuropathy. The characteristic feature of the present patient was that he manifested with sensorimotor dominant CIDP with demyelination proven by pathological examination. Polyneuropathy accompanied by hepatic malignant tumor is rare. As far as we could find, there has been only two case reports $(5,6)$. The patient in the first report was a 76-year-old man with HCC who showed gradual progression of numbness, muscle weakness and disturbance of the deep sensation in the limbs within a year. The patient in the second report showed severe motor deficit in all limbs associated with hepatic cholangiocarcinoma. However, his sensory function was normal. These patients were different from the present patient in that they did not have apparent demyelination but had axonal degeneration, and that the anti-GM1 ganglioside antibody was positive in each case. Although some patients with hepatitis B virus infection have been reported to have associated CIDP or axonal polyneuropathy $(7,8)$, they experienced deterioration of neuropathy during the active period of hepatitis. In the present patient, the serum hepatic enzyme levels were stable for more than 6 months and it is unlikely that his CIDP was caused by hepatitis B virus infection.

There is no proof that polyneuropathy in our patient was paraneoplastic in nature, and it is possible that CIDP and HCC were coincidental. However, the difficulties in walking and taking meals were clearly due to muscle weakness in the upper and lower limbs caused by CIDP, and these symptoms should not be misinterpreted as representing weakness due to general weakness caused by malignancies in cases such as this.

Part of this report was presented at the 148th Kinki regional meeting of the Japanese Society of Internal Medicine.

\section{References}

1) Research criteria for diagnosis of chronic inflammatory demyelinating polyneuropathy (CIDP). Report from an Ad Hoc Subcommittee of the American Academy of Neurology AIDS Task Force. Neurology 41: 617, 1991.

2) Kusunoki S. Carcinomatous neuropathy and neuropathy with $\operatorname{IgM}$ paraproteinemia. Saishin-igaku 50: 477, 1995 (in Japanese).

3) Tsukamoto T. Neurologic paraneoplastic syndromes: Annual review shinkei 1992 Chugai Igakusha, 1992, p. 267 (in Japanese).

4) Rowland LP. Merrit's Textbook of Neurology 9th ed. Williams \& Wilkins, Baltimore, 1995, p. 662.

5) Nishiyama K, Kurisaki H, Matsuda N, Kusunoki S, Takatsu M. Carcinomatous neuropathy associated with hepatic cell carcinoma: an autopsy case report. Neuromuscul Disord 3: 227, 1993.

6) Antoine JC, Mosnier JF, Lapras J, et al. Chronic inflammatory demyelinating polyneuropathy associated with carcinoma. J Neurol Neurosurg Psychiatry 60: 188, 1996.

7) Tsukada N, Koh CS, Inoue A, Yanagisawa N. Demyelinating neuropathy associated with hepatitis B virus infection. Detection of immune complexes composed of hepatitis B virus surface antigen. J Neurol Sci 77: 203, 1987.

8) Inoue A, Tsukada N, Koh CS, Yanagisawa N. Chronic relapsing demyelinating polyneuropathy associated with hepatitis B infection. Neurology 37: 1663, 1987. 